\title{
TRAGICIDADE E EXISTÊNCIA EM MARTIN HEIDEGGER*
}

\author{
Gilmário Guerreiro da Costa** \\ gilmario.filosofia@gmail.com
}

\author{
Um Nada \\ éramos, somos, seremos. \\ Paul Celan
}

Para Marcos Fernandes

RESUMO Este ensaio examina algumas possibilidades de diálogo da filosofia heideggeriana e o tema trágico. Concentramo-nos especialmente em três aspectos: a finitude humana, o conceito de angústia e o questionamento da estrutura de domínio prevalecente na técnica moderna. Como buscamos evidenciar, o gesto trágico fundamental não é o da violência que instaura, ou do aniquilamento que imagina desmentir todo o sentido, mas do movimento humano finito que segue nas bordas da existência, sem nunca intuir o quadro completo da sua vida.

Palavras-chave Trágico, Heidegger, finitude, angústia.

ABSTRACT This essay deals with some possibilities of the dialogue between Heideggerian philosophy and the question of the tragic. We focused mainly on three features: the human finitude, the concept of anxiety, and the questioning of the prevailing control structure in modern technology. We insisted on that the fundamental tragic act relates not to violence it inaugurates, or to annihilation, which imagines removal of all sense, but to the finite human

* Artigo submetido em 18/10/16. Aceito em 19/11/16.

** Universidade de Brasília/UnB. Brasília - DF - Brasil. 
movement, which follows the margins of existence, without grasping the full picture of his life.

Keywords Tragic, Heidegger, finitude, anxiety.

Em meio às múltiplas possibilidades que se abrem às suas investigações, o tema do trágico pode beneficiar-se do diálogo com três aspectos caros à filosofia heideggeriana: a finitude humana, a sua articulação com o conceito de angústia e o questionamento da estrutura domínio na lide simbólica com o mundo prevalecente na técnica moderna. Tanto o desenvolvimento dessa hipótese quanto a sua fundamentação e consequências merecem análise atenta às suas virtudes analíticas. Nesse percurso, sobressai o interesse pela inserção do Dasein $^{1}$ no mundo e na história, de maneira a afastar-se dos traços de idealidade e eternidade em que timbrou a investigação metafísica tradicional do homem, em busca de remeter o seu objeto a um fundamento inconcusso. Tais pressupostos confluem para a resistência também observável no pensamento trágico em assentir na afirmação da essência sub species aeternitas do homem. Nos múltiplos fios que enfeixam a sua existência, predominam os signos do precário e provisório nos quais se reencontram tragicidade e existência no pensamento heideggeriano.

É nesse sentido que o projeto heideggeriano de desconstrução da fixidez no estudo do ser presente na tradição metafísica pode abrir algumas vias promissoras de investigação do problema do trágico. Em especial, as consequências da precariedade de toda estabilização do sentido que os homens atribuem à sua mundaneidade. Heidegger busca mover uma experiência pensante que evidencia a estrutura contraditória do estudo do ser conforme desenvolvido na história da filosofia, de que decorreria o que ele chama de “esquecimento do ser”. Quando valorizamos o ser como permanente, o fazemos pela sua contraposição ao que passa. Sublinhamos o que subsiste no presente. Dessa maneira, é precisamente mediante uma operação temporal que buscamos ultrapassar a temporalidade do

1 Suscitou rico debate a tradução dessa palavra em português. Benedito Nunes (2012) e Ernildo Stein (1993) propuseram "ser aí", e Zeljko Loparic (1995), "estar aí". Na primeira tradução brasileira de Ser e tempo, Márcia de Sá Cavalcante (1995; 1993) optou por "pre-sença". De nossa parte, acolhemos a sugestão de Fausto Castilho, autor da mais recente tradução de Ser e tempo (2012b), de manter o termo no original, Dasein. Não é de todo satisfatório, mas tem a seu favor a possibilidade de assinalar o caráter controverso do seu uso em nossa língua. Quando a necessidade argumentativa e estilística exigiu seu correlato em português, usamos "estar-aí". 
ser. Evidencia-se aqui o núcleo de uma inconsistência que teima em ressurgir sob formas variadas.

Se ao Dasein importa a tarefa de assumir a sua existência autêntica, então terá de resistir à ilusão do encontro de verdades objetivas e imutáveis. Tal significa tomar-se a si como um ente cujo ser dá-se dentro dos horizontes da temporalidade, de que decorre o acento concedido à sua finitude. Por via semelhante, será precisamente a temporalidade o horizonte propício à compreensão mais plena do trágico. As categorias "presentificadoras" mostram-se inábeis para esse propósito. O herói trágico descobre a ascendência do passado sobre aquilo que ele veio a ser, mas não se prende a isso: projeta-se para além de si mesmo num futuro aberto a possibilidades as mais variadas. Disso não decorre necessariamente uma redenção que amaina todas as contradições; antes, a dificuldade de se apresentar o discurso abarcador de todas essas variações temporais sublinha as possibilidades e desacertos que o palco trágico não raro encena mediante figuras da finitude.

\section{2}

Em Ser e tempo, Heidegger detém-se em um tema caro à tradição filosófica: a questão da verdade. Buscou deslindá-la de seus ressaibos metafísicos, partindo de uma inserção dessa problemática no âmbito mesmo da história. Resistindo a quaisquer teorizações que pretendessem confiar a sua fundamentação e resultados a uma essência transcendental, esse projeto filosófico destitui a verdade de um fundamento último. Se a metafísica apresentou esse tema mediante o recurso à idealidade e eternidade, Heidegger o insere no horizonte do tempo. Não mais consente, nesse sentido, com as prerrogativas de infinitude e absoluto com frequência a ele atribuídas; antes, sustenta a sua finitude, ao mesmo tempo que pretende articular a sua relação com o Dasein e com a história. É nesse contexto que se pode compreender o conceito heideggeriano de verdade como desvelamento (aletheia). Assim entendida, emerge como desvelamento do nível antepredicativo que é condição de possibilidade do sentido da proposição.

A crítica heideggeriana ao essencialismo e à idealidade da metafísica é exemplar no modo como também repercute no lugar - e não lugar - da obra de arte. Nesse mudança na abordagem da obra, não mais se a utiliza como exemplo de ideias que se lhe superpõem, ao invés, o seu ponto de partida é a própria obra, a obra que está aí, que não é o simulacro de uma entidade ideal - um caminho interpretativo cujas linhas diretrizes já haviam sido preparadas pelo reclamo husserliano de "retorno às coisas mesmas" (Husserl, 2001, p. 168). Heidegger escreve: "O que é a arte? Nós procuramos sua essência [Wesen] na obra real” (Heidegger, 2010, p. 145). 
Em busca de um novo ponto de partida - novo sob as marcas do paradoxo, pois se situa na origem da fundamentação da verdade -, o autor de Ser e tempo explicita a sua insatisfação com a ênfase tradicional que a metafísica deu à essência em detrimento da existência: " $A$ 'essência' do Dasein reside em sua existência" (Heidegger, 2012b, §9, p. 139). Em outra passagem, reafirma esse ponto: "Entretanto, a 'substância' do homem não é o espírito como a síntese de alma e corpo, mas a existência" (Heidegger, 2012b, §25, p. 341). Além disso, a existência consiste na instância que possibilitará ao Dasein a compreensão de si mesmo, a qual não se fundamenta no sujeito puro, como premissa metódica transcendental livre da inconstância das possiblidades oferecidas pelo meio onde vive. Diferentemente, é tributária da odisseia do estar-aí, em todas as suas vicissitudes.

Vai-se delineando a possível inabilidade das antigas categorias da filosofia tradicional no tratamento desses problemas. Elas resultam insatisfatórias, entre outros motivos, devido ao seu caráter não originário. Para contornar essa dificuldade, exige-se o afastamento de todo o dogmatismo que pretendia fundar um conhecimento pretensamente original do Dasein sem nunca questionar as bases sobre as quais buscava estabelecer a sua investigação. O Dasein não possui o caráter de ser simplesmente dado. A sua determinação que se buscava estabelecer a partir do conceito de substância encobre-lhe o ser, pois incide no erro de afirmar precisamente a anterioridade ontológica da essência em relação à existência:

A substancialidade é o fio-condutor para a determinação do ente a partir do qual se responde à pergunta pelo quem. De modo inexpresso, o Dasein é de antemão concebido como subsistente. Em todo caso, a indeterminidade do seu ser implica sempre esse sentido-de-ser. Subsistência é, contudo, o modo-de-ser de um ente não-conforme-aoDasein (Heidegger, 2012b, §25, p. 333).

Se inexiste a essência última e fundante do aparecer, se à verdade não se oferece a segurança de um fundamento inconcusso, o estar aí do Dasein passa a lidar com a oscilação entre verdade e não verdade. A análise das consequências desse movimento conduz à afirmação da finitude da verdade, além de afastá-la de quaisquer lastros de remissão à transcendência, pondo-a no caráter prático do Dasein como ser-no-mundo. Nesse sentido, Heidegger sustenta que não são as assertivas predicativas o lugar em que reside a verdade: são precisamente elas que estão na verdade - há uma instância antepredicativa mais originária, base que possibilita a enunciação dessas assertivas, e que é precisamente a inserção do Dasein no mundo. Busca-se atestar a radicalidade dessa crítica por meio do conceito de ser-no-mundo (in-der-Welt-sein): "A elucidação do ser-no-mundo mostrou que não 'é' dado de pronto nem nunca se dá um mero sujeito sem 
mundo. Do mesmo modo que também não há afinal de pronto um eu isolado que se dê sem os outros" (Heidegger, 2012b, §25, p. 337).

Essa busca de um horizonte mais originário repercute igualmente na reflexão heideggeriana acerca das investigações ônticas peculiares à atividade científica:

A pesquisa científica efetua, ingênua e toscamente, a demarcação e a primeira fixação dos domínios-de-coisa. A elaboração do domínio em suas estruturas-fundamentais já é levada a cabo de certo modo pela experiência e pela interpretação pré-científica do âmbito-do-ser dentro do qual o domínio-de-coisa é ele mesmo delimitado (Heidegger, 2012b, §3, p. 51).

Com semelhante provocação, o filósofo manifesta o interesse em evidenciar a existência de um horizonte de compreensão prévio a todo empreendimento científico, destituindo-o da pretensão de um fazer livre de quaisquer préconceitos ou dívida a instâncias anteriores às suas pesquisas. Os seus métodos, posto que admiráveis pelo rigor e consistência, dependem de uma estrutura que precede o arranjo dos entes intramundanos sobre os quais incidirá o seu trabalho organizado.

O importante tema heideggeriano da autenticidade (Eigentlichkeit) é coerente com esses pressupostos. Toma a "verdade" a partir de um horizonte de temporalidade, com a ênfase posta na finitude do Dasein, bem como a finitude de qualquer conhecimento teórico. $\mathrm{Na}$ esclarecedora formulação de Benedito Nunes, o Dasein em sua finitude "adere a si mesmo e ao mundo, sem passagem para o infinito" (1998, p. 30). O desvelamento da finitude do Dasein implica o compromisso rigoroso com uma fundamentação mais modesta e de caráter "transitivo". Como se pode observar, semelhante estudo repercute no âmbito mesmo do projeto fundacionista, o qual, em vez de ser o fautor da expectativa metafísica de superação da finitude, encontra-se ele mesmo fundado nos múltiplos desdobramentos da temporalidade.

Pode-se aqui indagar, não sem alguma perplexidade, dos motivos por que o Dasein ocultou a sua autenticidade no seio da metafísica. Segundo Heidegger, há no Dasein uma tendência ao encobrimento, que se liga à dificuldade em se lidar com a angústia - disposição de humor que manifesta ao Dasein como possibilidade a sua existência autêntica. É por essa razão que ele foge, em busca de uma espécie de refúgio na metafísica e na esfera pública. $\mathrm{O}$ desejo de pensar as coisas em sua radicalidade, que às vezes responde pelo nome de filosofia, explica por que a compreensão do Dasein deve guiar-se pela visada no seu estar enquanto vinculado ao "aí" $(D a-),{ }^{2}$ à sua facticidade, e não remeter- 
se a um fundamento último. A faticidade do Dasein ressalta que, sem que houvesse escolhido, o homem está lançado no mundo. É este o espaço e tempo da sua condição originária, e não o trato privilegiado com proposições lógicoargumentativas. Primeiramente, o homem aparece em sua mundaneidade, nos traços concretos e infungíveis da sua existência, e não a partir da estrutura do cogito ou do sujeito transcendental.

\section{3}

A atenção às consequências da primazia da temporalidade no exame dos temas peculiares à metafísica permite assinalar a diferença ontológica entre ser e ente. Heidegger ocupa-se do que julga ser o caráter originário da existência, afim à ampliação do conceito de tempo, do que ele denominou de "estases da temporalidade [die Ekstasen der Zeitlichkeit]" (Heidegger, 2012b, §65, p. 895). ${ }^{3}$ $\mathrm{O}$ acento posto pela tradição em categorias do presente, atravessadas por uma "pura sequência-de-agoras sem começo, nem fim” (Heidegger, 2012b, §65, p. 895), foi o responsável pela obliteração da diferença ontológica, pensando o ser como um ente que é desde já permanente. Em contrapartida, ao se incluírem nessa nova proposta o passado e o futuro, é possível deslindar a suposta identidade entre ambos, pois é pelo ser que o ente é. O ente pertence a um modo de determinação daquilo que é; o ser, por sua vez, pelo seu vigor ontológico, apenas se deixa ver pelo indeterminado da sua manifestação.

Todos esses esforços da investigação heideggeriana à procura de uma compreensão mais originária do ser do Dasein fazem sobressair a sua mundaneidade como matriz explicativa essencial. Semelhante orientação articula-se com o estudo da força de influência da tradição no que tange à interpretação que o Dasein busca elaborar de si mesmo:

O Dasein "é" seu passado no modo do seu ser, o qual, para dizer rudemente, "se gesta" cada vez a partir de seu futuro. Em cada modo de ser que lhe é próprio e portanto também no entendimento-de-ser que lhe é próprio, o Dasein ingressa numa interpretação-do-Dasein que lhe sobrevém e na qual ele cresce. A partir desta, ele se entende de imediato e, em certo âmbito, constantemente. Esse entendimento abre e regula as possibilidades de seu ser. Seu próprio passado - o que significa sempre o passado de sua "geração" - não segue atrás do Dasein mas, ao contrário, sempre o precede (Heidegger, 2012b, §6, p. 81).

3 É aqui infeliz a opção do tradutor: Ekstase não corresponde a "estase", mas a "êxtase". A confusão entre os dois parônimos torna obscura a passagem, fazendo sobressair a ideia de estagnação (estase), e não de dinamismo (êxtase), precisamente o que Heidegger está pontuando em toda essa passagem. 
O passado do Dasein - o que se entende aqui por sua geração, e não referido a uma possível individualidade radical - notabiliza-se por uma espécie de "ascendência" fundamental sobre os caminhos que se lhe vão abrindo. A força da tradição imiscui-se nas possibilidades de compreensão do Dasein, sugerindo tratar-se de estrutura cuja ultrapassagem é, em rigor, inexequível. Entretanto, Heidegger sustenta a possibilidade de um relacionamento que se poderia chamar, ao menos provisoriamente, crítico no trato com essa herança que nos precede e a partir da qual temos o desafio de seguir realizando alguns ensaios de autenticidade ao longo da existência.

Destarte, não é legítimo pensar a dinâmica da temporalidade de maneira unilateral, pois também se ligam aos "êxtases da temporalidade" o presente e o futuro, futuro esse no qual se pro-jetam as múltiplas possibilidades do Dasein, em relação às quais o passado é o esteio e o horizonte, mas não uma instância de determinação. A esse respeito, é mister nos anteciparmos criticamente a alguns "perigos" da tradição, dos quais sobressaem o dogmatismo e a resistência ao questionamento. Isso porque amiúde ela encobre e esconde o legado que herda para as gerações posteriores, tentando fazê-lo parecer algo evidente em si mesmo; em tal processo de velamento, obscurecimento, assemelha-se às distorções de significado empreendidas pelas ideologias. Ela fecha o caminho que leva à revelação das fontes das quais se elaboraram conceitos e categorias: "A tradição que assim se faz dominante, em vez de tornar acessível de pronto e no mais das vezes o que ela 'transmite', ao contrário, encobre-o" (Heidegger, 2012b, §6, p. 85). Heidegger não intenta negar o passado representado pela tradição com o intuito de destruí-lo. Antes, pretende acercar-se de uma apropriação crítica dos seus objetos. Esse exercício heideggeriano é um estudo preparatório da crítica que apresentará mais especificamente à tradição metafísica.

Toda essa linha investigativa apresenta interesse decisivo no estudo do trágico. Tome-se como elemento inicial o Édipo-rei, de Sófocles. Nele, o relacionamento do protagonista com o oráculo enfrenta um sentimento de estranheza com relação a um passado que já fora concebido como tendo sido heroico. A noção de tempo finito e circular, que preside a tragédia grega, torna problemática a expectativa de uma remissão absoluta, de uma vitória exequível sobre o passado. Nesse contexto, o seu herói, mesmo em pleno exílio, suscita a desconfiança de não se tratar propriamente de um recurso sacrificial para proteger uma cidade manchada pelos erros do protagonista. É provável que se trate por vezes de uma escolha motivada justamente pela descrença no pretenso valor dessa cidade. ${ }^{4}$

4 Podem, aqui, acrescentar-se o Prometeu agrilhoado, de Ésquilo, o Filoctetes sofocleano e, no cenário moderno, o Navio fantasma, de Richard Wagner. 
Tais são, em linhas gerais, as considerações acerca do passado e da tradição no horizonte de compreensão de que parte o Dasein. No caso do futuro, a reflexão pode agora aproximar-se de uma abordagem mais plena do Dasein. Ganha relevo o importante tema heideggeriano do projeto, cuja significação é que o Dasein deve lidar com o estar-adiante-de-si-mesmo (Sich-vorweg-sein), esteio por meio do qual emerge o cuidado (Sorge). Nos termos de Ernildo Stein, o Dasein é o único ser que "compreende o Ser que tem o futuro agora e sofre pelo futuro agora. Para o qual o futuro não é aquilo que ainda vem, mas aquilo que desde sempre já está vindo, isto é, já sempre é incorporado na existência" (1993, p. 234). O futuro não se configura com traços de distanciamento, pois nos atinge e afeta no presente da expectativa da sua manifestação. E aqui também, mais uma vez, o exame heideggeriano da temporalidade manifesta a sua virtude interpretativa no estudo do trágico. Esclarece em cifra mais adequada as perplexidades do herói trágico, especialmente na sequência das reviravoltas no rumo da existência a que o enredo artístico constrói a forma. Ele sofre pelo entrelaçamento do passado, presente e futuro. Aflige-o o futuro que está vindo, a dificuldade de se postergar, mesmo apenas no nível da consciência, numa tentativa de se buscar conforto para os seus efeitos.

Aos temas da mundaneidade e do projeto, liga-se o da alteridade. Não se compreende com radicalidade o Dasein caso se o remeta a uma essência de jaez intemporal extramundano; tampouco é legítimo referi-lo a um cogito cartesiano ou a uma mônada leibniziana, ou qualquer outra forma em que ele aparece sob atributos permeados de idealidade. Ele não apenas é um ser-no-mundo, mas também um ser-com (Mitsein). Ele é no mundo-com-os-outros. É um modo de ser que apresenta caráter multifacetado. Pode conduzir à autonomia, na medida em que o Dasein, na lide cotidiana com os outros, respeita-lhes as diferenças nesse rico e complexo horizonte de alteridade. No entanto, não é incomum a ocorrência do inverso, ou seja, que o estar-aí-com-os-outros se enfeixe em relações heterônomas, imprimindo o esquecimento de si em virtude de apresentar-se sob a tutela de outrem. A heteronomia revela-se ainda quando o nivelamento implica o desdouro da supressão das diferenças, concebidas como um aspecto de importância secundária. Nessa teorização, estabelece-se a oposição fundamental entre cotidianidade (Alltäglichkeit) e abertura ${ }^{5}$ (Erschlossenheit). No primeiro caso, o homem permanece imerso na mais profunda heteronomia, 
advinda do seu servilismo ao pensamento de a-gente-impessoal (das Man) ${ }^{6}$ preso ao estreitamento do relacionamento "coisístico" com os entes intramundanos. Lança o Dasein e a sua interpretação na esfera pública (Öffentlichkeit), ${ }^{7}$ que promove o nivelamento (Einebnung) e a medianidade (Durchschnittlichkeit). É a própria impossibilidade da existência autêntica e castração das diferenças: "Distanciamento, mediania e nivelamento, como modos-de-ser de a-gente, constituem o que conhecemos como 'a publicidade'. Ela regula de pronto toda interpretação-do-mundo e toda interpretação-do-Dasein e tem razão em tudo" (Heidegger, 2012b, §27, p. 367).

Há, pelo menos, duas respostas possíveis a esse processo: a resistência ou a adesão. Na primeira, o homem exila-se da dominância inautêntica do seu quotidiano em busca da autenticidade (Eigentlichkeit). Na segunda, há $\mathrm{o}$ abandono de si-mesmo sob a forma da obediência às demandas da esfera pública. Surpreendentemente, a abertura (Erschlossenheit), a saída dessas teias de dominação do "impessoal" não se alcança mediante o ajuste da racionalidade crítica e de aparato conceitual rigoroso. Heidegger esclarece que semelhante ultrapassagem quem o oferece é uma disposição fundamental de ânimo, a angústia (Angst). ${ }^{8}$ Não se trata de uma dor de caráter determinado, mas de uma disposição que faz as relações com os entes intramundanos se desestabilizarem, não havendo para ela um referente determinado. Ela abre a mundaneidade do mundo e o Dasein "como ser possível, ou melhor, como aquele que unicamente a partir de si mesmo pode ser como isolado no isolamento" (Heidegger, 2012b, $\S 40$, p. 525). Destarte, nessa paciente elaboração existencial o mundo não se revela primeiramente à reflexão e abstração, e sim a partir dos planos próprios e indeterminados da angústia. Descerra a possibilidade de compreensão originária do Dasein porque o remete a instâncias anteriores às das categorias da tradição filosófica raramente questionadas em seu ser fundado - animal racional, ser humano, ser social: "Mas só na angústia reside a possibilidade de uma assinalada abertura, porque ela isola [vereinzelt]" (Heidegger, 2012b, §40, p. 533). Tal a razão de encaminhar às sendas de superação da heteronomia e do impessoal. No entanto, sejam os planos de indeterminação da angústia, sejam os seus efeitos, não abrem ao ser a passagem para o infinito do seu fundamento, mas o estranhamento da finitude e do sem-fundo da existência.

6 Das Man pode ser traduzido por "a gente", "impessoal”. Neste trabalho, alternamos o uso dessas possibilidades de tradução.

7 Fausto Castilho opta por traduzi-la por "publicidade".

8 Será objeto de estudo em um texto posterior de Heidegger, Que é metafísica, no qual se relacionará com a negação do ente em sua totalidade: o nada. 


\section{4}

Predomina na angústia um sentimento difuso de estranheza (unheim), como se não nos sentíssemos em casa (Heim). Enquanto se encontrava encerrado na mediana cotidiana, o Dasein fugia mediante a "certeza tranquila" de si mesmo. Agora, por força dessa disposição de ânimo, move-se da segurança das interpretações assentes à mais abissal "des-familiaridade" (Unheimlichkeit), imerso em um estado no qual o consolo metafísico perde a sua efetividade. Impelido para fora da interpretação pública e heterônoma do "impessoal" (das Man), se lhe oferece ocasião oportuna ao encontro da autenticidade (Eigentlichkeit):

O diante-de-quê da angústia é completamente indeterminado. Essa indeterminidade não só deixa factualmente indecidido qual o ente-do-interior-do-mundo a ameaçar, mas significa que ente-do-interior-do-mundo em geral não é "relevante". Nada do que é utilizável e subsistente no interior-do-mundo tem a função daquilo diante de que a angústia se angustia. [...] Que o ameaçador não esteja em parte alguma caracteriza o diante-de-quê da angústia (Heidegger, 2012b, §40, pp. 521, 523).

Mediante as disposições existenciais, como a da angústia, os homens desvinculamse de qualquer ente intramundano. É uma dimensão que não pode ser reduzida a nenhuma estrutura ôntica particular. A linguagem pertence a essa mesma estrutura, e necessita, para os que dela se aproximam, igualmente de uma experiência genuína, ou seja, infensa à pura determinação.

A liberdade do Dasein encena-se precisamente nesse jogo oscilante entre a busca da autonomia e o seu transvio rumo à heteronomia: "No ser-adiantadoem-relação-a-si como ser para o poder-ser mais-próprio reside a condiçãoda-possibilidade ontológico-existenciária do ser livre para as possibilidades existenciais próprias" (Heidegger, 2012b, §41, p. 539). Não se vincula aos atributos de um sujeito transcendental, mas ao estar-aí que, no movimento de anteceder-se a si mesmo, reencontra as suas possibilidades mais autênticas. Ao preceder-a-si-mesmo ligam-se o já-ser-em (faticidade) e o ser-junto-a (decadência).

Finalmente, a angústia também possibilita a revelação do ser-para-a-morte (Sein zum Tode). Heidegger salienta que o Dasein não realiza a possibilidade da morte fortuitamente, pois existindo "já está lançado nessa possibilidade". Ele esclarece ainda que se distinguem entre si a angústia e o medo com a morte. Se este mostra-se ligado a um objeto determinado, a primeira reflete acerca da própria finitude do Dasein. A angústia "é a abertura de que o Dasein existe como ser projetado para o seu final. Com o que se esclarece o conceito existenciário do morrer como ser projetado para o poder-ser mais-próprio, irremetente e insuperável” (Heidegger, 2012b, §50, p. 693). 
Em que pesem a sutileza e aspiração à radicalidade dessas proposições filosóficas, não lhe faltaram críticos agudos. Um deles foi Theodor Adorno (2008), que lhe dedicou leitura crítica atenta. Nessa meditação heideggeriana seria discernível, em grande medida, apenas uma forma requintada de jargão, a que Adorno chamou "jargão da autenticidade" (Jargon der Eigentlichkeit). A seu ver, semelhante filosofia articulava-se com o novo ambiente forjado pelo fascismo. A partir de 1933, todo uma rede de expressões filosóficas, ou radicadas em Heidegger, ou nele inspiradas, reverberam esse procedimento. Se confrontados com a realidade histórica, os matizes da angústia então entretecidos com estilo grave e pretensamente sublime, perdem sua força e apelo. A experiência do século XX destitui da sua excepcionalidade existencial um sentimento constitutivo da vida cotidiana, com as múltiplas cores dos seus traumas e temores.

Também resulta problemática a insistência no reencantamento mítico que atribui ostensivamente às palavras, mas cujos contornos esconde sob a exibição da sua pretensa revelação. Em grande medida, semelhante uso da linguagem esforça-se por envolver sub-repticiamente no véu da vagueza do seu vocabulário a pátina das interpretações históricas em que se esteia sua elaboração. O fervor com que se exalta o homem em sua precariedade, por exemplo, não deve enganar o seu propósito de manter as coisas exatamente no estado em que se encontram. Embora se lamente o sofrimento, não é bom ocupar-se da sua superação. É mais autêntico assumi-lo. O descuido de semelhante transformação age subrepticiamente em benefício da ideologia opressora. No caso de insistir "na transformação do homem abstrato em sentido hegeliano, isso apenas tensiona as rédeas; não há exatamente elevação, e sim a continuação da velha ideologia opressora" (Adorno, 2008, p. 436).

Não menos discutível seria a apresentação do problema da identidade pressuposta no entendimento heideggeriano da autenticidade. Não obstante ter escrito textos dedicados às inter-relações entre identidade e diferença, a sua filosofia ainda pagaria tributo considerável às estruturas do idealismo (Adorno, 2008, p. 480). Se o filósofo frankfurtiano tem razão, o caráter sinuoso da reflexão heideggeriana não é capaz de encaminhar adequadamente o liame dialético entre identidade e alteridade, por meio do qual se dissolvem as pretensões à totalidade. Tal descuido justifica ilusões afins às do fascismo, infenso a quaisquer fissuras que denunciem o arbítrio de sua autofundação e da interpretação com que imagina descerrar o sentido da história. Todas essas operações se assentam no ludíbrio da identidade a si sem restos. Em outros termos, a dimensão autoritária da identidade imagina serem os seus contornos absolutos e um tesouro a defender contra todo tipo de ameaça. No caso específico do jargão da autenticidade, ligase a uma essência permanentemente ameaçada pelos ruídos da vida cotidiana, de cujos riscos se deve precaver. 
Embora julgue ser isenta de ideologia, ou operar em nível originário anterior a quaisquer orientações ou distorções sistemáticas de significado, atravessam os contornos da autenticidade elementos ideológicos persistentes - espécie de vingança dialética da ideologia: "O jargão da autenticidade é ideologia enquanto linguagem, abstração feita a todo conteúdo particular" (Adorno, 2008, p. 492).

As críticas adornianas revelariam haver menos mistérios entre o céu e a terra do que sonham as impostações da linguagem heideggeriana. A profundidade de que se revestiram as investigações fenomenológicas em torno à existência autêntica enfeitiçou toda uma geração de escritores e filósofos, mas sequer se aproximou da tão decantada radicalidade que presumia exibir. Em 1935, oito anos após o lançamento de Ser e tempo, Heidegger haveria de retomar as suas indagações em torno ao tema do estranhamento, na obra Introdução à metafísica. A ousadia agora demonstrada revelava o desejo de aprofundamento dos temas desenvolvidos nas obras anteriores, posto que não desmentissem as suspeitas críticas de Adorno.

\section{5}

É no capítulo 4 de Introdução à metafísica, denominado "A delimitação do ser", que Heidegger se detém na meditação acerca da estranheza originária do homem. Para isso, desenvolve uma interpretação, bastante peculiar, do célebre primeiro estásimo da Antígona, de Sófocles. Os versos iniciais dessa passagem são estes:

Muitos prodígios há; porém nenhum

maior do que o homem (S. Ant. 332)

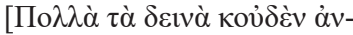

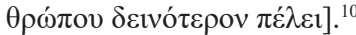

Também conhecida como "Ode ao homem", o coro estaria a princípio celebrando as conquistas da humanidade (Pereira, 2012, p. 121). No entanto, o significado efetivo dessa passagem está longe de alcançar consenso entre os intérpretes, embora colha a admiração de quase todos eles como obra de arte: "Is the view of 'Man' (333 ö $v \theta \rho \omega \pi \circ \varsigma, 347 \alpha \dot{\alpha} v \eta \dot{\rho})$ predominantly favourable, predominantly unfavourable, mixed, or neutral?" (Griffith, 1999, p. 179). Tais escolhas interpretativas repercutem no modo como se traduz o termo deina: "Or, to put it another way, should we translate the key term of the opening line, 


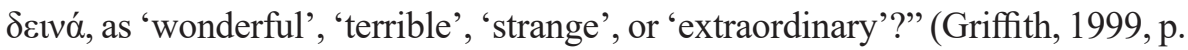
180). Esta é uma das questões de interesse decisivo para Heidegger, que propõe, a esse respeito, a seguinte tradução, na qual ganha relevo a compreensão de que nada sobressai em estranheza ao homem:

Muitas são as coisas estranhas, nada, porém, há de mais estranho do que o homem (Heidegger, 1987, p. 170).

[Vielfältig das Unheimliche, nichts doch über den Menschen hinaus Unheimlicheres ragend sich regt] (Heidegger, 1983, p. 155).

Essa estranheza articula-se com um tema obsedante para Heidegger, o da resistência à determinação, intimamente associado ao da vigência da própria finitude humana. $\mathrm{O}$ deinon liga-se à angústia perante o vigor que predomina na totalidade do ente. $\mathrm{O}$ filósofo discorre na sequência acerca do que chama de "vigor da violência" (Gewalt-tätigkeit): "A palavra, "instaurar o vigor da violência', damos aqui um sentido essencial, que em princípio transcende o significado corrente segundo o qual indica, às mais das vezes, arbítrio e crueldade" (Heidegger, 1987, p. 173). Os fatos históricos relacionados ao ano de publicação dessa obra suscitam compreensível embaraço a quem se depara com essa meditação acerca do vigor da violência. Dois anos antes os nazistas haviam chegado ao poder, e com eles Heidegger mantinha relações bastante amistosas. Daí ser incontornável um impulso inicial a inter-relacionar o plano político vigente com essas reflexões filosóficas. O contexto mais amplo em que se insere essa passagem, no entanto, apresenta dificuldades a semelhante aproximação. O filósofo, em sua leitura dos versos sofocleanos, empenha-se por mover a sua interrogação em campo infenso a toda sorte de determinação e espírito utilitário. Claramente se ocupa de plano ontológico prévio a todo plano de organização pragmática do ente peculiar ao exercício da política. Todo esse projeto pode revelar-se frágil ou mesmo insustentável, evidentemente. Porém, não se nos afigura comprometido com o uso instrumental da violência que vigeu durante o horror nazista.

Não faltou a espíritos finos a elaboração de hipóteses diferentes. Jacques Taminiaux, por exemplo, apresenta ressalvas críticas à meditação heideggeriana acerca da violência originária, pois lhe parecia vincular-se, ainda que indiretamente, ao pano de fundo da política nazista da época:

É inegável a força dessa análise. Mas igualmente inegável é o equívoco que pesa sobre ela, na medida em que a decisão ontológica que ela invoca, no contexto de 1935, equivale a prevenir-se contra toda crítica possível à violência da ação do fundador do Terceiro Reich. Porque a Alemanha está destinada aqui a recomeçar mais originariamente o que iniciaram os fundadores do Dasein grego, tudo se passa como se os pré-socráticos e os 
trágicos aprovassem antecipadamente o regime, em que pesem as críticas marginais sutis que Heidegger dirige à ideologia oficial (Taminiaux, 1995, p. 213). ${ }^{11}$

Embora reconheçamos haver certa justeza nessa análise, mantemos algumas dúvidas a respeito. Com o benefício da distância histórica, não se poderia negar a aproximação, entre trágica e oportunista, de Heidegger com o nazismo. Contudo, a análise heideggeriana funda-se num gesto de provocação contra o âmbito do controle do mundo da vida que encontra dificuldades de relacionar-se com os governos fascistas nos quais se timbrava a administração total da sociedade. De todo modo, o elogio da criação de mundos como marca do itinerário humano não necessita absolutamente de pagar tributo a qualquer sorte de violência, por mais decantada filosoficamente que seja.

Em grande medida, a força do trágico reside na ambiguidade com a qual envolve todos os atos de violência. Fazê-lo seria presumir controlar forças cujo desfecho não pode ser menos que imprevisível. O que instaura não é obra da violência, mas da ousadia do amor. Trata-se do exato sentimento que impulsiona a heroína homônima da Antígona, de Sófocles. ${ }^{12}$ Amor trágico, porque move os fios de uma ação inscrita em enigma, mas cujo apelo escuta e lho responde. Em vez dos planos de comensurabilidade instrumental da atividade, sobressai a entrega e serena acolhida das suas consequências. O gesto trágico fundamental não é o da violência que instaura, ou do aniquilamento que imagina desmentir todo o sentido, mas do movimento humano finito que segue nas bordas da existência, sem nunca intuir o quadro completo da sua vida.

Se de fato são justas essas ressalvas, como se poderia compreender a força e atividade da violência cujo sentido o autor de Ser e tempo imagina descerrar? E, mais importante para os interesses do nosso trabalho, como se ligam à questão do estranhamento e do trágico? Ferindo gosto peculiar pelo paradoxo, Heidegger sustenta que o sentido dessa violência refere-se não à separação com que se subordinam os entes todos a um determinado regime de poder. Ao invés, é justamente de cooperação e entrega que se trata. A estranheza, o terrível (deinon) desse movimento, reside no modo como se indispõe contra os mecanismos de controle e previsibilidade assentes no mundo moderno e

11 "Incontestable est la puissance de cette analyse. Mais incontestable aussi est la lourde équivoque qui pèse sur elle dans la mesure où la décision ontologique qu'elle invoque, dans le contexte de 1935, équivaut à prémunir de toute critique possible la violence de l'action du fondateur du troisième Reich. Puisque l'Allemagne est ici vouée à recommencer plus originairement ce qu'initièrent les fondateurs du Dasein grec, tout se passe comme si les Présocratiques et les tragiques cautioinnaient par avance le régime, en dépit des critiques marginales qu'à mots couverts Heidegger adresse à l'idéologie officielle" (Taminiaux, 1995, p. 213).

12 Antígona responde ao seu opositor, Creonte: "Não nasci para odiar mas sim para amar" (S. Ant. 523). 
nos campos do esquecimento do ser afins ao desenvolvimento da metafísica a partir de Platão e Aristóteles:

Assim a violência do vigor é considerada dentro de um âmbito em que o critério da existência é dado pelo acordo e contrato de equiparação e mútua assistência e, em consequência, se despreza, necessariamente, toda e qualquer violência, como simples perturbação e violação (Heidegger, 1987, p. 173).

Vincula-se à atividade humana a possibilidade de instaurar esse vigor com vistas a resistir à determinação que preside a estrutura da organização do ente em nossa época. Não se subordina ao trato meramente instrumental da sua essencialidade que se opera no interesse de satisfazer às expectativas do cálculo imposto pela vontade de poder. Sua violência é terrível por contrariar todo o universo de cálculo de riscos da dominância da técnica moderna.

Quando se empenha em dominar o homem por meio da subjugação da sua essência aos limites determinados de uma definição, a orientação técnicocientífica imagina-se familiarizada com o objeto. No entanto, a enormidade e estranheza perturbadora do humano oferta aos discursos triunfalistas apenas a sombra erradia do seu acontecer. Por ser terrível, estranho, o homem torna qualquer esforço de decifração conceitual do seu existir uma contradição de termos. Talvez aqui se intua o núcleo da vitalidade da sabedoria trágica, de um ensino que não se atém a lições delimitadas acerca da vida, como se falasse por meio de uma voz que se respeita justamente porque não dispõe de vigor e provocação. Diferentemente, a sabedoria trágica interessa-se pela situação paradoxal que nos acena em sua radicalidade apenas por fazê-lo estranha e distanciadamente, ou seja, na pura indeterminação da interpelação a que nos lança.

Adiante, Heidegger busca esclarecer um pouco mais o sentido de "estranhamento" com o qual está trabalhando. Não se refere exatamente ao seu efeito sobre as nossas emoções, e sim ao que nos afasta da familiaridade. Em vez de apresentar-se como mais um atributo do homem, ela conforma a sua essencialização própria. Outros dois versos auxiliam na compreensão e confirmação dessas hipóteses - ou, mais apropriadamente, caminhos - de leitura. O primeiro é este: "de tudo capaz [pantoporos]" (S. Ant. 360). E, na sequência: "Ao Hades somente não pode escapar [aporos]" (S. Ant. 360). O apuro poético de Sófocles é aqui admirável, no jogo que entretece entre os vocábulos pantoporos e poros, inclinando os próprios versos a repercutirem o cerne das hesitações e conflitos que a ode expressa. A tradução de Heidegger intenta fazer-lhe justiça, embora esteja mais próxima dos seus postulados filosóficos, do que da arte mesma do poeta grego: "Überall hinausfahrend unterwegs, erfahrungslos ohne Ausweg / kommt er zum Nichts” (Heidegger, 1983, p. 156). E, na tradução 
de Emanuel Carneiro Leão da tradução de Heidegger: "Pondo-se a caminho em toda parte, desprovido de experiência / e em aporia, chega ele ao Nada" (Heidegger, 1987, p. 170).

Seja a passagem de Sófocles, seja a interpretação de Heidegger, sublinham o limite intransponível do humano, apesar de todos os seus recursos: a morte. Tomada a partir desse plano, sobressai na existência humana a sua precariedade e finitude. Os demais caminhos palmilhados com astúcia e indústria revelam o seu vigor não no plano da ostentação dos seus objetos; antes, é da violência contra a repetição e o nivelamento que retiram o seu valor. Os umbrais do tempo e da morte, longe de lhe retirarem todo consolo e virtude, apresentam coerentemente na figura da fragilidade o vigor da sua indeterminação. A ausência de saída da morte evidencia a virtude das sendas que o homem abre, com as quais inscreve não os traços da sua eternização, mas dos êxtases e caprichos do tempo. Matriz da cura das ilusões da determinação pretensamente eterna com a qual presumia ultrapassar o tempo que presidia todos os seus movimentos. Cura igualmente do esquecimento do fundamento nulo sobre que o homem movimenta o seu existir. A estranheza aqui revela que o homem não pode plenamente habitar num dado espaço. Ele sempre está além. A compreensão do Nada indica a matriz da finitude do seu existir, e não qualquer sorte de acumpliciamento com o niilismo.

A existência humana busca responder aos enigmas e perplexidades, aos impasses da sua trajetória. Em grande medida, trata-se de mais uma peça no esforço de pensar o humano para além de toda determinação, que esbarra nesse limite de toda significação, o Nada. Heidegger faz a seguinte observação a esse respeito:

Por toda a parte o homem se abre caminhos. Atreve-se em todos os setores do ente, do vigor imperante que se impõe. E por isso se vê lançado fora de todo caminho. Somente deste modo se abre toda a estranheza daquele que é o que há de mais estranho. Não apenas por experimentar em toda a sua estranheza o ente na totalidade. Não só porque nela rompe, como aquele que instaura o vigor, o que lhe é familiar. Ele se torna em tudo isso o que há de mais estranho porque, estando em todos os caminhos em aporia, sem saída alguma, se acha expulso de qualquer referência (Heidegger, 1987, pp. 174-175).

O raciocínio é bastante sutil, de uma sutileza tal que não apenas provoca admiração, mas também inclina à desconfiança. De um lado, por deslocar-se em todos os campos do ente, o homem assinala não a sua instalação no espaço que circunscreve, mas a sua enormidade e estranheza que se multiplicam. Quanto mais investe na organização dessa estrutura, mais conhece paradoxalmente os signos múltiplos da sua ignorância, que, em vez de ser superada, agiganta-se. De outro lado, pode-se questionar em que medida, na negação do dado, não se nos depara o plano da acolhida de uma precariedade capaz de viger não exatamente 
o estranho, mas a única espécie de familiaridade que a sorte nos reserva. Se há estranheza nisso, tal se liga apenas à configuração finita e frágil de tudo a que os homens chamam lar. Pode-se, evidentemente, avançar a hipótese de o âmbito familiar abrigar em seu interior a persistência do estranho que lhe confere vida e vigor. Semelhante contradição talvez desvele o fundo trágico da existência humana, a que os versos de Sófocles admiravelmente oferecem a forma.

O outro verso a que Heidegger aludira é este: "grande é a cidade [hupsipolis]; / mas logo a perde [apolis] /quem por audácia incorre no erro" (S. Ant. 370). Trata-se de mais um lance de grande arte do escritor grego. O comentário de Heidegger tenta evocar dialogicamente a riqueza dos versos: "Não se evoca o poros mas a polis. Não se indicam todos os caminhos do domínio do ente, mas o fundamento e lugar da existência humana. O ponto de convergência e cruzamento de todos os caminhos, a polis" (Heidegger, 1987, p. 175). A dimensão da polis circunscreve o espaço da consolidação do humano no campo da história. No entanto, tal como se observou no âmbito da aproximação da totalidade do ente, também o cenário da polis acena para a impossibilidade mesma da determinação do homem no espaço político que primeiramente forjou, e depois o acolheu. É que a polis descerra ao homem o sem-lugar último dos seus esforços de habitação. Os limites dessa experiência não apenas assinalam as fronteiras do seu movimento, mas também, e sobretudo, os planos de indeterminação que nenhuma cidadela estará em condições de absorver e traduzir adequadamente.

Heidegger recusa a interpretação evolucionista dos eventos que se seguem no estásimo sofocleano. Além de ser inábil para ouvir a sorte de interrogação poética desses versos, infensa à celebração dos usos instrumentais da administração sistemática dos entes, também enfraquece a força vigente nas origens, destinando-a a simples ensaio primitivo que seria superado por exercícios mais sofisticados. A articulação proposta recupera justamente a força disruptiva da origem, cuja violência seria domada para fins da efetividade da organização do mundo da vida em etapas posteriores. A temporalidade que preside esse movimento nada tem de progressiva, mas de ex-tática, capaz de surpreender certa ordem com o fito de instaurar a vigência de outra experiência (Heidegger, 1987).

Ao homem se lhe deparam aporias, impasses, sem-caminhos como resultado paradoxal da sua abertura de caminhos. São atos criadores de caminhos, a princípio; no entanto, findam por condicionar o homem ao círculo estreito da sua própria criação. O cerne da estranheza reside assim na força instauradora de novas vias conducentes ao cerceamento de outros vias. A instauração positiva entrelaçase no negativo do seu próprio gesto: "A aporia consiste [Die Ausweglosigkeit besteht], ao invés, no fato de ele ser sempre reconduzido aos caminhos por ele mesmo abertos, aferrando-se a seus percursos, enredando-se no já percorrido" (Heidegger, 1987, p. 180). 
É nesse contexto que Heidegger faz uma observação percuciente acerca da obra de arte: "A obra de arte [Das Werk der Kunst] não é, em primeiro lugar, obra [Werk], porquanto é confeccionada, é feita [gewirkt, gemacht], mas porque opera o Ser em um ente [das Sein in einem Seienden er-wirkt]" (Heidegger, 1987, p. 181). O vigor da obra reside na abertura em que insiste a sua manifestação. Na sua tessitura incorporam-se os impasses do humano e sua estranheza fundamental. Dessa maneira pode lhe reenviar as questões que são o apanágio do seu pensamento: "A paixão do saber está em investigar questões [Die Leidenschaft des Wissens ist das Fragen]" (Heidegger, 1987, p. 182).

Alguns anos depois, em 1953, no final da conferência sobre a técnica, o filósofo torna a enfatizar a importância instauradora do ato de apresentar uma questão: "Pois questionar é a piedade do pensamento [Denn das Fragen ist die Frömmigkeit des Denkens]" (Heidegger, 2012a, p. 38; Heidegger, 2000, p. 36). Em ambos os casos, aproxima-se questão de dois impulsos ou disposições de ânimo: paixão e piedade. Seriam manifestações mais originárias que a razão. Nesse sentido, a questão a que nos impele a obra difere de um conjunto articulado de enunciados com os quais se pretende, por exemplo, refutar determinado argumento. Ela é antes o movimento instaurador dos caminhos afins à sabedoria e à piedade com as quais se acolhe a manifestação do ser do homem em sua estranheza e inaptidão fundantes. Toda essa reflexão configura temas e desafios na contramão da vontade de poder e domínio prevalentes na vida moderna, a qual se poderia denominar de época antitrágica por excelência, não fossem os vetores da sua insolência e ignorância aconselharem precisamente a definição irônica e dialeticamente oposta.

\section{Referências}

ADORNO, T. W. "La jerga de la autenticidade". In: Dialéctica negativa; La jerga de la autenticidad. Tradução de A. B. Muñoz. Madrid: Ediciones Akal, 2008.

GRIFFITH, M. “Antigone”. Ed. and comment. Cambridge: Cambridge University Press, 1999.

HEIDEGGER, M. "Einführung in die Metaphysik”. Frankfurt: Vittorio Klostermann, 1983.

"Introdução à metafísica". Apresentação e tradução de E. C. Leão. Rio de Janeiro: Tempo Brasileiro, 1987a.

. "Introdução à metafísica". Tradução de E. C. Leão. 3a. ed. Rio de Janeiro:

Tempo Brasileiro, 1987b.

. "Ser e tempo". Vol. 2. Tradução de M. S. Cavalcante. 3a. ed. Petrópolis: Vozes, 1993. 
Vozes, 1995.

. "Ser e tempo". Vol. 1. Tradução de M. S. Cavalcante. 5a. ed. Petrópolis: . "Die Frage nach der Technik". In: Vorträge und Aufsätze. Frankfurt: Vittorio Klostermann, 2000.

. "A origem da obra de arte". Tradução de I. Azevedo e M. A. Castro. São Paulo: Edições 70, 2010. Edição bilíngue.

. "A questão da técnica". In: Ensaios e conferências. Tradução de E. C. Leão, G. Fogel e M. S. C. Schuback. 8a. ed. Petrópolis: Vozes; Bragança Paulista: Ed. Universitária São Francisco, 2012a.

. "Ser e tempo". Tradução de F. Castilho. Campinas: Ed. Unicamp; Petrópolis: Vozes, 2012b. Edição bilíngue.

HUSSERL, E. "Logical investigations". Tradução de J. N. Findlay. London, New York: Routledge, 2001.

LOPARIC, Z. "Ética e Finitude". São Paulo: EDUC, 1995.

NUNES, B. "Crivo de papel”. 2a. ed. São Paulo: Ática, 1998.

Loyola, 2012.

. "Passagem para o poético: filosofia e poesia em Heidegger". São Paulo:

PEREIRA, M. H. R. “Introdução e comentários”. In: SÓFOCLES. Antígona. Trad. M. H. R. Pereira. 10a. ed. Lisboa: Calouste Gulbenkian, 2012.

STEIN, E. "Seminário sobre a verdade: lições preliminares sobre o parágrafo $44 \mathrm{de}$ Sein und Zeit". Petrópolis: Vozes, 1993.

TAMINIAUX, J. "Le théâtre des philosophes: la tragédie, l'être, l'action". Grenoble: Jérôme Millon, 1995. 